\title{
USE OF SUBLAMINAR BANDS FOR ADOLESCENT IDIOPATHIC SCOLIOSIS - A SYSTEMATIC REVIEW
}

\author{
USO DAS BANDAS SUBLAMINARES EM CIRURGIA PARA ESCOLIOSE IDIOPÁTICA \\ DO ADOLESCENTE - REVISÃO SISTEMÁTICA DA LITERATURA
}
USO DE LAS BANDAS SUBLAMINARES EN CIRUGÍA PARA ESCOLIOSIS IDIOPÁTICA DEL ADOLESCENTE - REVISIÓN SISTEMÁTICA DE LA LITERATURA

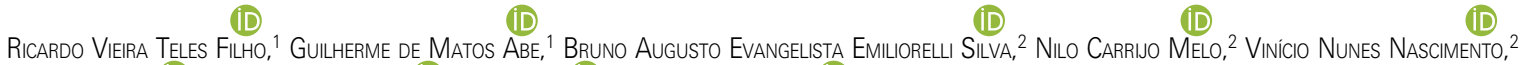 \\ Pedro Felisbino JR, ${ }^{2}$ Marcelo Fouad Rabahl, ${ }^{3}$ Sergio Daher, ${ }^{2}$ Murilo Tavares Daher ${ }^{1,2}$ \\ 1. Universidade Federal de Goiás, Faculdade de Medicina, Department of Orthopedics - DOT/FM/UFG, Goiânia, Goiás, GO, Brazil. \\ 2. Centro de Reabilitação e Readaptação Dr Henrique Santillo - CRER, Goiânia, Goiás, GO, Brazil. \\ 3. Universidade Federal de Goiás, Faculdade de Medicina, Department of Clinical Medicine, Goiânia, Goiás, GO, Brazil.
}

\begin{abstract}
Objective: In 2003, Mazda et al. introduced a new device for surgical correction of Adolescent Idiopathic Scoliosis (AIS) called sublaminar bands (SB). The reduction principle that SBs use is posteromedial spinal translation, similar to Luque's wiring, but using polyester bands. Methods: We performed a systematic review of the literature on this subject, evaluating the technique in terms of coronal correction, sagittal correction, bleeding, mean surgical time, loss of correction, infection, pseudoarthrosis, and neurological and other complications. The total search resulted in 14 articles published over the last 10 years. We found that the use of SBs in hybrid AIS correction instrumentations provides an average correction of $69 \%$ in the frontal plane, a $5^{\circ}$ increase in thoracic kyphosis (average increase of 55\%), overall complications of $4.5 \%$, and no neurological complications were reported in any of the studies analyzed.. The mean blood loss was $682.5 \mathrm{~mL}$ and the mean surgical time was 228.6 minutes. Conclusions: We conclude that the literature suggests that this instrumentation is safe, allows good correction in the frontal plane and great correction in the sagittal plane. As for complications, mean surgical time, and blood loss, their averages are lower than those of other constructions used for AIS. Level of evidence IIA; Systematic review.
\end{abstract}

Keywords: Spinal Curvatures; Surgery; Prostheses and Implants; Orthopedic Fixation Devices.

\section{RESUMO}

Objetivo: Em 2003, Mazda et al. apresentaram um novo dispositivo para correção cirúrgica da Escoliose ldiopática do Adolescente (EIA) denominado Bandas Sublaminares (BS). O princípio de redução que as BS utilizam é a translação posteromedial da coluna vertebral, semelhante àquela dos fios de Luque, através do uso de bandas de poliéster. Métodos: Realizou-se uma revisão sistemática da literatura sobre o tema, avaliando a técnica em relação à correção coronal, correção sagital, sangramento, tempo operatório médio, perda de correção, infecção, pseudoartrose, complicações neurológicas e outras complicações. A busca resultou em 14 artigos publicados nos últimos 10 anos. Resultados: Observamos que o uso das BS em instrumentações híbridas para correção da ElA proporciona uma redução média de $69 \%$ no plano frontal e aumento da cifose torácica de $5^{\circ}$ (aumento médio de 55\%), $4,5 \%$ de complicações em geral e nenhuma complicação neurológica foram apresentadas em todos os estudos analisados. A média de sangramento foi 682,5 mL e o tempo cirúrgico médio de 228,6 minutos. Conclusões: Conclui-se que a literatura sugere que essa instrumentação é segura, permite boa correção no plano frontal e grande correção no plano sagital. Em relação às complicações, tempo cirúrgico médio e sangramento, todas essas variáveis em média são inferiores se comparadas as das demais construções utilizadas para ElA. Nível de evidência IIA; Revisão sistemática.

Descritores: Curvaturas da Coluna Vertebral; Cirurgia; Próteses e Implantes; Dispositivos de Fixação Ortopédica.

\section{RESUMEN}

Objetivo: En 2003, Mazda et al. presentaron un nuevo dispositivo para corrección quirúrgica de la Escoliosis Idiopática del Adolescente (ElA) denominado Bandas Sublaminares (BS). El principio de reducción que las BS utilizan es la traslación posteromedial de la columna vertebral, similar a aquella de los hilos de Luque, a través del uso de bandas de poliéster. Métodos: Se realizó una revisión sistemática de la literatura sobre el tema evaluando la técnica con relación a la corrección coronal, corrección sagital, sangrado, tiempo operatorio promedio, pérdida de corrección, infección, pseudoartrosis, complicaciones neurológicas y otras complicaciones. La búsqueda resultó en 14 artículos publicados en los últimos 10 años. Resultados: Obsenvamos que el uso de las BS en instrumentaciones híbridas para la corrección de la EIA proporciona una reducción promedio de $69 \%$ en el plano frontal y aumento de la cifosis torácica del $5^{\circ}$ (aumento promedio de 55\%); 4,5\% de complicaciones en general y ninguna complicación neurológica fueron presentadas en todos los estudios analizados. El promedio de sangrado fue $682,5 \mathrm{~mL}$ y el tiempo quirúrgico promedio de 228,6 minutos. Conclusiones: Se concluye que la literatura sugiere que esta instrumentación es segura, permite buena corrección en el plano frontal y gran corrección en el plano sagital. Con relación a las complicaciones, tiempo quirúrgico promedio y sangrado, todas estas variables en promedio son inferiores si comparadas con las demás construcciones usadas para ElA. Nivel de evidencia IIA; Revisión sistemática.

Descriptores: Curvaturas de la Columna Vertebral; Cirugía; Prótesis e Implantes; Dispositivos de Fijación Ortopédica.

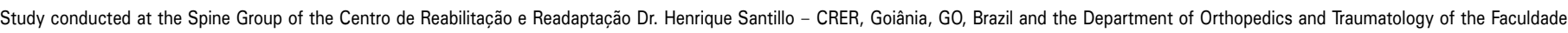
de Medicina da Universidade Federal de Goiás - DOT/FM/UFG, Goiânia, Goiás, GO, Brazil.

Correspondence: Murilo Tavares Daher. Rua 70, 351, apto 302, Jardim Goiás, Goiânia, GO, Brasil. 74810-350. murilodaher@uol.com.br 


\section{INTRODUCTION}

Surgical strategies for the treatment of adolescent idiopathic scoliosis (AIS) continue to be developed and improvement in correction power is notable. ${ }^{1}$ Pedicle screws have become the standard, but they are already being associated with a decrease in thoracic kyphosis and a risk of junctional kyphosis., ${ }^{2,3}$ In 2003, Mazda et al. introduced the use of a new device: sublaminar bands (SB). The reduction principle that SBs use is the posteromedial translation of the spine, similar to that of Luque wires, but using malleable polyester bands instead of metallic wires. ${ }^{4}$ Recent literature suggests that using this type of instrumentation allows good curve correction in the frontal plane and it has been shown to be particularly effective in the sagittal plane with improved restoration of thoracic kyphosis. ${ }^{5,6}$

SBs consist of polymeric strips made of polyester, whose curved rigid edges are introduced under the vertebral lamina. The sublaminar insertion of polyester bands is simple and because of their greater contact surface they offer advantages over steel wires, permitting greater traction with a lower risk of fracture of the lamina. ${ }^{7}$

The bands are tensioned level by level with a special tool, pulling the vertebra by the lamina and guiding them to the rods. ${ }^{8}$ The strength of the rod to band connection is equivalent to the connections using screws or hooks, allowing conventional deformity correction maneuvers such as compression and distraction. They can also be used in combination with pedicle screws, especially in the lumbar region. ${ }^{4}$

Studies about SBs, although scarce, emphasize the safety of the method and the efficiency of its posteromedial translation in the restoration of sagittal alignment, possibly superior in this respect to the use of screws. In this sense, we sought to conduct a systematic review of the current literature to evaluate the correction power in the coronal and sagittal planes, as well as safety and complications, in order to include SBs in the surgical therapeutic arsenal available for the treatment of AIS.

\section{METHODS}

A systematic review of the literature on the subject was conducted according to the Cochrane Handbook for Systematic Reviews. We reviewed studies reporting cases of surgical treatment for AIS using hybrid constructions that used SB. Data analysis focused on the descriptive evaluation of the extracted information. The search for articles was conducted in the PubMed, Scopus, and Google
Scholar electronic databases. The keywords and the search strategy used were: ("adolescent idiopathic scoliosis") AND ("sublaminar band" OR "sublaminar bands" OR "posteromedial translation" OR "universal clamp" OR "sagittal correction" OR "sagittal balance") AND ("pedicle screw" OR "hybrid construction" OR "hybrid instrumentation").

We limited the search to works published in English from 2010 forward. The last search was conducted by the authors at the end of February 2019. The searches were conducted independently by two researchers who collected the abstracts. We identified additional works from the references of the included studies. Unpublished works and those not reviewed by peers were not considered.

The exclusion criteria were articles written in a language other than English, animal and cadaver studies, in vitro studies, technical notes, letters to the editor, and articles that did not specifically contain results reports. The three-level selection system was used for the final analysis of the full articles.

Two authors independently extracted the data using an extraction form. Disagreements were resolved through discussion or consensus with a third author. The corresponding author of the study was contacted to collect any missing information. The information was extracted using special tables designed for the review-based study. The tables contained the following variables: coronal correction, sagittal correction, cervical alignment, bleeding, mean surgical time, loss of correction, infection, pseudoarthrosis, neurological complications, and other complications.

\section{RESULTS}

We found a total of 158 articles with the search strategy. After applying the inclusion and exclusion criteria, 14 articles remained for analysis. (Figure 1) Two of them were produced in Italy, one in Iran, one in Japan, and ten in France. The selected articles are described in Table 1.

Except for in one study, all the patients studied in the other articles participated in a minimum follow-up of two years to evaluate complications and loss of correction. (Table 1) The patients in twelve of the studies were submitted to the same hybrid construction surgical technique combining pedicle screws below the inflection point and thoracic sublaminar bands above the inflection point with posteromedial translation for thoracic correction. Two studies differed from this technique, using pedicle screws together with SBs in the thoracic region above the inflection point. (Table 1)

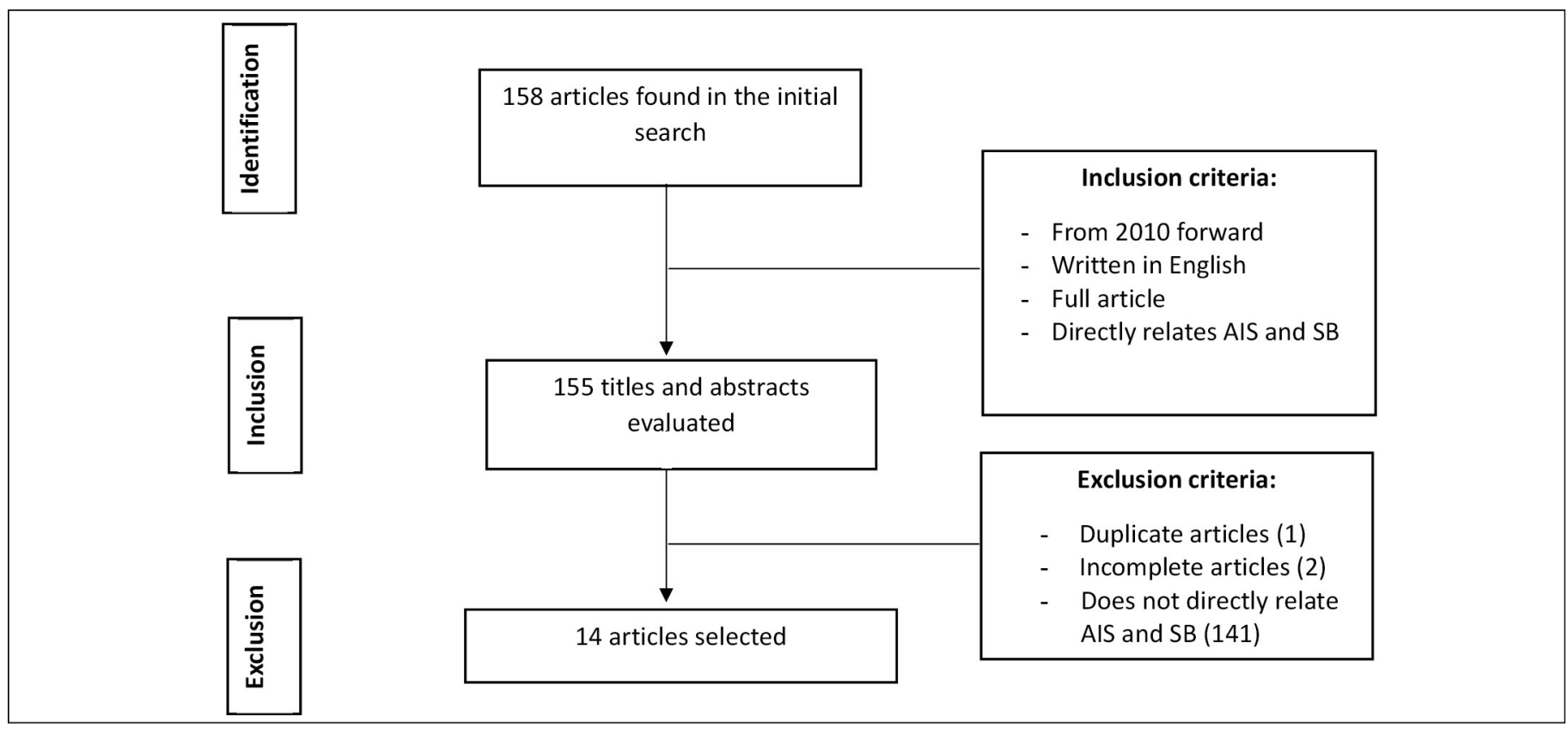

Figure 1. Search strategy. 
Table 1. Selected articles

\begin{tabular}{|c|c|c|c|c|c|c|}
\hline Title & Authors & Location & Year of publication & $\mathbf{N}$ & Treatment & $\begin{array}{l}\text { Minimum } \\
\text { follow-up }\end{array}$ \\
\hline $\begin{array}{c}\text { How To Optimize Axial Correction Without } \\
\text { Altering Thoracic Sagittal Alignment In Hybrid } \\
\text { Constructs With Sublaminar Bands: Description } \\
\text { Of The "Frame" Technique }\end{array}$ & $\begin{array}{l}\text { Iharreborde, B. } \\
\text { et al. }^{19}\end{array}$ & France & 2019 & 60 & $\begin{array}{l}60 \text { patients submitted to } \\
\text { thoracic sublaminar bands }\end{array}$ & 2 years \\
\hline $\begin{array}{c}\text { Interest Of T1 Parameters For Sagittal } \\
\text { Alignment Evaluation Of Adolescent Idiopathic } \\
\text { Scoliosis Patients }\end{array}$ & Pesenti, S. et al. ${ }^{18}$ & France & 2015 & 29 & $\begin{array}{l}29 \text { patients submitted to } \\
\text { thoracic sublaminar bands }\end{array}$ & 2 years \\
\hline $\begin{array}{l}\text { Do Sublaminar Polyester Bands Affect The } \\
\text { Outcomes Of Postoperative Infections After } \\
\text { Adolescent Idiopathic Scoliosis Surgery? }\end{array}$ & Issa, S.P. et al. ${ }^{17}$ & France & 2016 & 524 & $\begin{array}{l}524 \text { patients submitted to } \\
\text { thoracic sublaminar bands } \\
\text { analyzed only in terms of } \\
\text { infection }\end{array}$ & 2 years \\
\hline $\begin{array}{c}\text { Titanium Vs Cobalt Chromium: What Is The } \\
\text { Best Rod Material To Enhance Adolescent } \\
\text { Idiopathic Scoliosis Correction With Sublaminar } \\
\text { Bands? }\end{array}$ & $\begin{array}{c}\text { Angelliaume, A. } \\
\text { et al. } .^{16}\end{array}$ & France & 2016 & 70 & $\begin{array}{l}70 \text { patients submitted to } \\
\text { thoracic sublaminar bands ( } 35 \\
\text { titanium, } 35 \text { cobalt chromium) }\end{array}$ & 2 years \\
\hline $\begin{array}{c}\text { Comparison Of Clinical And Radiologic } \\
\text { Outcome Of Adolescent Idiopathic } \\
\text { Scoliosis Treated With Hybrid Hook-Screw } \\
\text { Instrumentation Versus Universal Clamp } \\
\text { System }\end{array}$ & $\begin{array}{l}\text { Hassankhani, E.G. } \\
\text { et al. }^{15}\end{array}$ & Iran & 2016 & 28 & $\begin{array}{c}28 \text { patients submitted to } \\
\text { thoracic sublaminar bands and } \\
28 \text { patients submitted to hook- } \\
\text { screw }\end{array}$ & 2 years \\
\hline $\begin{array}{l}\text { Correction Of Hypokyphosis In Thoracic } \\
\text { Adolescent Idiopathic Scoliosis Using } \\
\text { Sublaminar Bands: A 3d Multicenter Study }\end{array}$ & $\begin{array}{l}\text { Ilharreborde, B. } \\
\text { et al. }{ }^{14}\end{array}$ & France & 2017 & 35 & $\begin{array}{l}35 \text { patients submitted to } \\
\text { thoracic sublaminar bands }\end{array}$ & 2 years \\
\hline $\begin{array}{c}\text { Hybrid Constructs Pedicle Screw With Apical } \\
\text { Sublaminar Bands Versus Pedicle Screws } \\
\text { Only For Surgical Correction Of Adolescent } \\
\text { Idiopathic Scoliosis }\end{array}$ & $\begin{array}{l}\text { Palmisani, M. et } \\
{\text { al. }{ }^{13}}\end{array}$ & Italy & 2018 & 19 & $\begin{array}{c}19 \text { patients submitted to } \\
\text { apical sublaminar bands with } \\
\text { pedicle screws and } 18 \text { patients } \\
\text { submitted only to pedicle } \\
\text { screws }\end{array}$ & 2 years \\
\hline $\begin{array}{c}\text { Efficacy And Safety Of Posteromedial } \\
\text { Translation For Correction Of Thoracic Curves } \\
\text { In Adolescent Idiopathic Scoliosis Using A } \\
\text { New Connection To The Spine: The Universal } \\
\text { Clamp }\end{array}$ & Mazda, K. et al. ${ }^{4}$ & France & 2009 & 75 & $\begin{array}{l}75 \text { patients submitted to } \\
\text { thoracic sublaminar bands }\end{array}$ & 2 years \\
\hline $\begin{array}{l}\text { Hybrid Constructs For Tridimensional } \\
\text { Correction Of The Thoracic Spine In } \\
\text { Adolescent Idiopathic Scoliosis }\end{array}$ & $\begin{array}{l}\text { llharreborde, B. } \\
\text { et al. }{ }^{\text {P }}\end{array}$ & France & 2010 & 75 & $\begin{array}{l}75 \text { patients submitted to } \\
\text { thoracic sublaminar bands } \\
\text { and } 75 \text { patients submitted to } \\
\text { thoracic hooks }\end{array}$ & 2 years \\
\hline $\begin{array}{c}\text { Use Of The Universal Clamp In Adolescent } \\
\text { Idiopathic Scoliosis For Deformity Correction } \\
\text { And As An Adjunct To Fusion: 2-Year } \\
\text { Follow-Up }\end{array}$ & $\begin{array}{l}\text { De Gauzy, J. S. } \\
\text { et al. }{ }^{12}\end{array}$ & France & 2011 & 29 & $\begin{array}{l}29 \text { patients submitted to } \\
\text { thoracic sublaminar bands }\end{array}$ & 2 years \\
\hline $\begin{array}{l}\text { Posterior Surgery For Adolescent Idiopathic } \\
\text { Scoliosis With Pedicle Screws And Ultra- } \\
\text { High Molecular Weight Polyethylene Tape: } \\
\text { Achieving The Ideal Thoracic Kyphosis }\end{array}$ & $\begin{array}{l}\text { Imagama, S. et } \\
\text { al. }^{11}\end{array}$ & Japan & 2012 & 30 & $\begin{array}{c}30 \text { patients submitted to PSTH- } \\
\text { DVR }\end{array}$ & 2 years \\
\hline $\begin{array}{c}\text { Sagittal Alignment Of The Cervical Spine In } \\
\text { Adolescent Idiopathic Scoliosis Treated By } \\
\text { Posteromedial Translation }\end{array}$ & $\begin{array}{l}\text { Ilharreborde, B. } \\
\text { et al. }{ }^{10}\end{array}$ & France & 2013 & 49 & $\begin{array}{l}49 \text { patients submitted to } \\
\text { thoracic sublaminar bands }\end{array}$ & 2 years \\
\hline $\begin{array}{l}\text { The Universal Clamp Hybrid System: A Safe } \\
\text { Technique To Correct Deformity And Restore } \\
\text { Kyphosis In Adolescent Idiopathic Scoliosis }\end{array}$ & La Rosa et al. ${ }^{9}$ & Italy & 2013 & 62 & $\begin{array}{l}62 \text { patients submitted to } \\
\text { thoracic sublaminar bands }\end{array}$ & 1 year \\
\hline $\begin{array}{c}\text { Adolescent Idiopathic Scoliosis Correction } \\
\text { Achieved By Posteromedial Translation Using } \\
\text { Polyester Bands: A Comparative Study Of } \\
\text { Subtransverse Process Versus Sublaminar } \\
\text { Fixation }\end{array}$ & Hirsch, C. et al. ${ }^{8}$ & France & 2014 & 20 & $\begin{array}{l}20 \text { patients submitted to } \\
\text { thoracic sublaminar bands } \\
\text { and } 20 \text { patients submitted to } \\
\text { subtransverse bands }\end{array}$ & 2 years \\
\hline
\end{tabular}

Two of the 14 studies, those published by Mazda L. et $a l .{ }^{4}$ and Ilharreborde B. et al., ${ }^{7}$ used the same cohort of 75 patients. Thus, the total number of patients who underwent surgery using the thoracic SB technique in the 14 articles was 1030. For purposes of calculating means and parameter results, these two studies were considered a single study, but for the purpose of quantifying articles that address any of the parameters analyzed here, they were considered distinct articles. When considering the 12 studies that used only thoracic SBs, the total number of patients was 981. (Table 1)
Four studies compared the outcomes of the groups submitted to the technique using SBs to another group that underwent a different surgical technique: one compared them to those of a technique using subtransverse bands, another to the use of thoracic hooks, another to a technique with thoracic screws, and the last compared them to those of a technique using thoracic hooks and screws. One study used SBs in two groups, differentiated only by the material used for the longitudinal rods (titanium or cobalt chromium). (Table 1)

All 14 studies analyzed the surgical technique according to at 
least one of the following parameters: coronal correction power, sagittal correction power, loss of coronal correction, mean bleeding volume, mean surgical time, occurrence of complications, occurrence of infection, and occurrence of pseudoarthrosis and 2 studies analyzed cervical alignment. A single study was focused only on an analysis of the occurrence of infection and pseudoarthrosis. (Table 2)

None of the 11 studies that analyzed the occurrence of neurological complications reported any complications of this nature. Similarly, none of the 6 studies that analyzed the occurrence of pseudoarthrosis reported the occurrence of this condition during follow-up. (Table 2)

Ten studies analyzed the occurrence of complications from the surgical technique. There was a total of 20 complications obtained among the 423 patients evaluated in these studies, for a complication rate of $4.73 \%$. When we considered those 9 studies that used the same thoracic SB-only technique separately, there was a total of 16 cases of complications or $4.1 \%$. (Table 2 )

These same 10 studies also analyzed the occurrence of other types of postoperative complications, observing a total of 19 different complications for an overall rate of $4.5 \%$. When we considered only the 9 out of these 10 studies that used the same thoracic SB-only technique, the total of different complications was 17 or $4.33 \%$. (Table 2) The natures of these 17 complications were pleural effusion (3), intestinal disorder (2), superior mesenteric artery syndrome (2), debilitating pain (5), and proximal junctional kyphosis (5).

Seven studies, totaling 266 patients, analyzed the volume of intraoperative bleeding, reporting a mean overall blood loss of 682.5 $\mathrm{mL}$. When we considered only the 5 out of these 7 studies that used the same thoracic SB-only technique, the mean value was $645 \mathrm{~mL}$
(Table 2). Nine studies, totaling 315 patients, analyzed the mean surgical time, but one of them did not report the value obtained and was excluded from the calculation of the overall mean surgical time, which was 228.6 minutes. When we considered only the 7 out of these 8 studies that used the same thoracic SB-only technique, the overall mean was 220.4 minutes. (Table 2)

Seven studies, totaling 777 patients, analyzed the occurrence of postoperative infections, observing a total of 32 cases for an overall infection rate of $4.12 \%$. (Table 2 )

\section{Coronal correction}

Eleven studies analyzed the power of coronal correction for the technique used in the immediate postoperative period, with a mean coronal correction of $70.3 \%$. (Figure 2) When we considered only the 9 out of these 11 studies that used only thoracic SBs, the overall mean was $69.22 \%$. (Table 3)

\section{Sagittal correction}

Thirteen studies analyzed the power of sagittal correction. However, only 10 studies in the sample provided data about the power of sagittal correction in the immediate postoperative period. (Table 4) All of these 10 studies used the same technique of only thoracic SBs. The overall mean sagittal correction power of these 10 studies in the immediate postoperative period was $5.95^{\circ}$. (Figure 3)

\section{Cervical alignment}

Two studies, totaling 78 patients, analyzed the effect of the surgical technique on the cervical spine. Correction of cervical lordosis in the immediate postoperative period was $10.9^{\circ}$ and $10.3^{\circ}$ in these two studies for mean immediate correction of $10.6^{\circ}$. 5,14

Table 2. Variables analyzed.

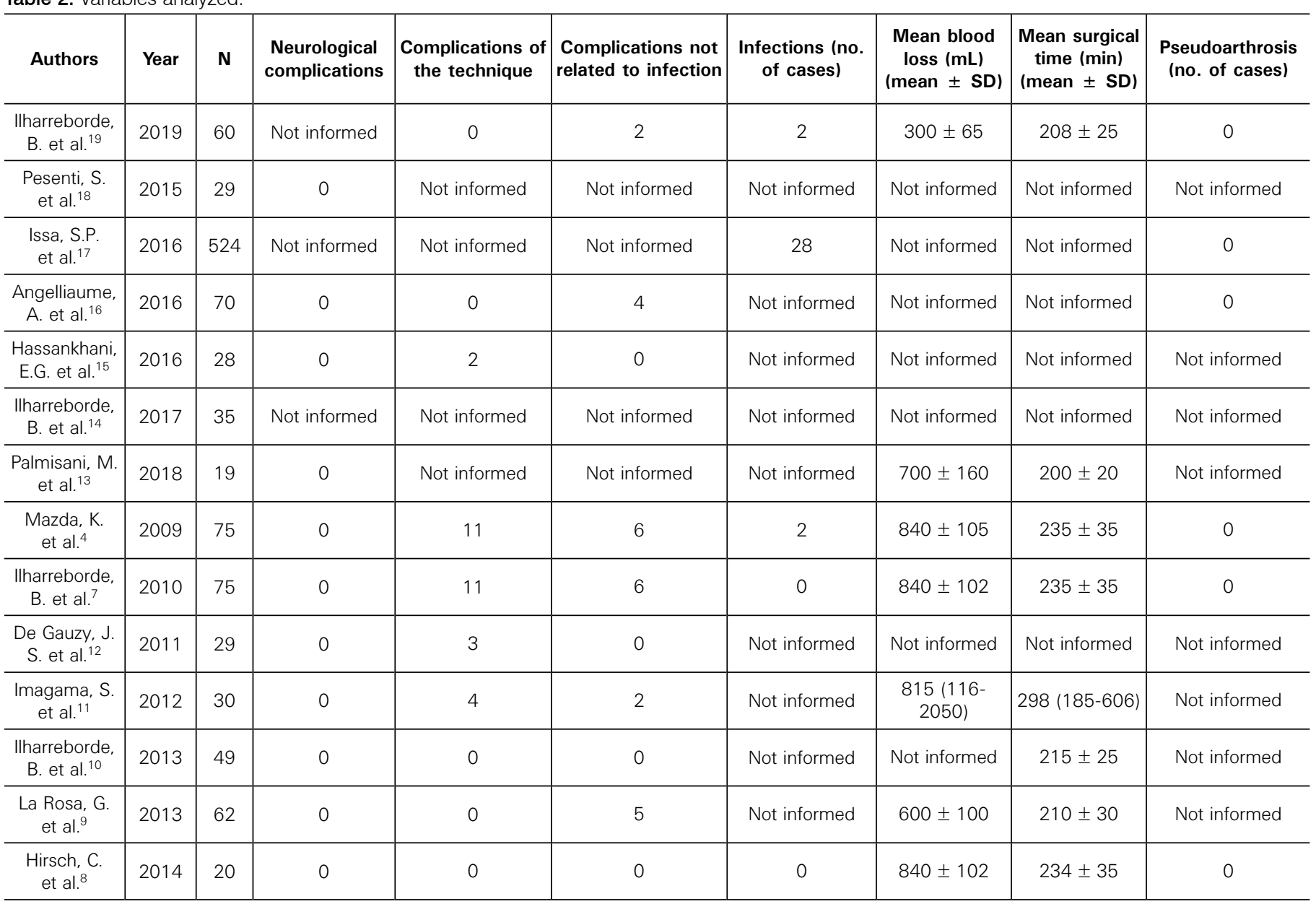




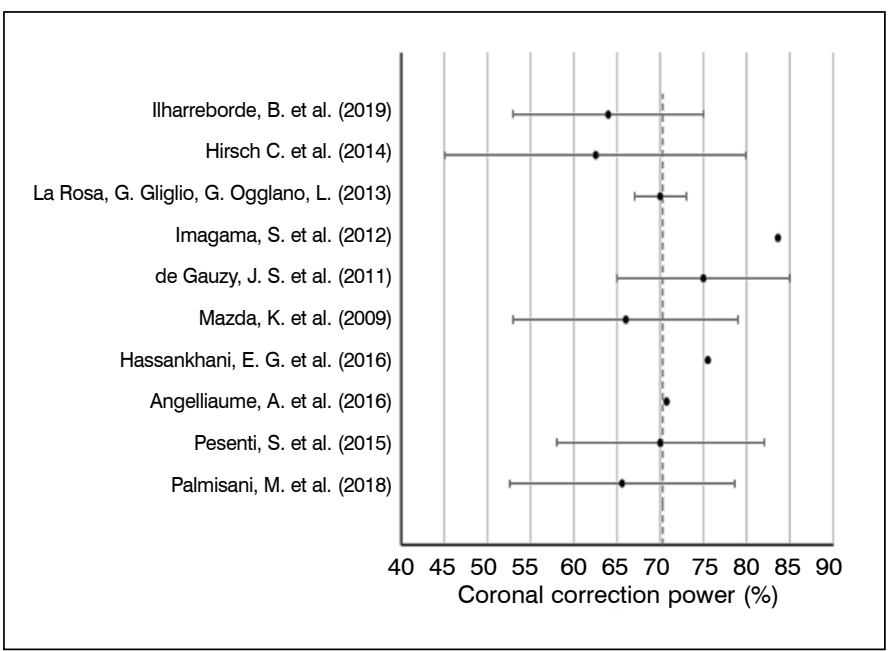

Figure 2. Mean coronal correction.

Table 3. Coronal correction.

\begin{tabular}{c|c|c|c}
\hline Authors & Year & N & $\begin{array}{c}\text { Coronal correction power } \\
(\%) \text { (mean } \pm \text { SD) }\end{array}$ \\
\hline Hirsch, C. et al. ${ }^{8}$ & 2014 & 20 & $62.5 \pm 17.4$ \\
\hline La Rosa et al. $^{9}$ & 2013 & 62 & $70 \pm 3$ \\
\hline${\text { Ilharreborde, B. et al. }{ }^{10}}^{1}$ & 2013 & 49 & Not informed \\
\hline Imagama, S. et al. $^{11}$ & 2012 & 30 & 83.60 \\
\hline De Gauzy, J. S. et al. ${ }^{12}$ & 2011 & 29 & $75 \pm 10$ \\
\hline Ilharreborde, B. et al. $^{7}$ & 2010 & 75 & $66.4 \pm 10.8$ \\
\hline Mazda, K. et al. ${ }^{4}$ & 2009 & 75 & $66 \pm 13$ \\
\hline Palmisani, M. et al. ${ }^{13}$ & 2018 & 19 & $65.6 \pm 13$ \\
\hline Ilharreborde, B. et al. ${ }^{14}$ & 2017 & 35 & Not informed \\
\hline Hassankhani, E.G. et al. ${ }^{15}$ & 2016 & 28 & 75 \\
\hline Angelliaume, A. et al. ${ }^{16}$ & 2016 & 70 & 70.75 \\
\hline Issa, S.P. et al. ${ }^{17}$ & 2016 & 524 & Not informed \\
\hline Pesenti, S. et al. ${ }^{18}$ & 2015 & 29 & $70 \pm 12$ \\
\hline Ilharreborde, B. et al. ${ }^{19}$ & 2019 & 60 & $64 \pm 11$ \\
\hline Overall mean & & & $70.3 \%$ \\
\hline $\begin{array}{c}\text { Mean with only thoracic } \\
\text { sublaminar bands }\end{array}$ & & & $69.2 \%$ \\
\hline
\end{tabular}

Table 4. Sagittal correction.

\begin{tabular}{|c|c|c|c|}
\hline Authors & Year & $\mathbf{N}$ & $\begin{array}{l}\text { Sagittal correction power }\left({ }^{\circ}\right) \\
(\text { mean } \pm \text { SD) }\end{array}$ \\
\hline Hirsch, C. et al. ${ }^{8}$ & 2014 & 20 & 4.9 \\
\hline La Rosa, et al. ${ }^{9}$ & 2013 & 62 & 5 \\
\hline Ilharreborde, B. et al. ${ }^{10}$ & 2013 & 49 & $14.5 \pm 10$ \\
\hline Imagama, S. et al. ${ }^{11}$ & 2012 & 30 & $\begin{array}{c}\text { Only the final value after follow- } \\
\text { up was informed }\end{array}$ \\
\hline De Gauzy, J. S. et al. ${ }^{12}$ & 2011 & 28 & 2.16 \\
\hline Ilharreborde, B. et al. ${ }^{7}$ & 2010 & 75 & 6.5 \\
\hline Mazda, K. et al. ${ }^{4}$ & 2009 & 75 & 6.5 \\
\hline Palmisani, M. et al. ${ }^{13}$ & 2018 & 19 & $\begin{array}{l}\text { Only the value of the group with } \\
\text { hypokyphosis informed }\end{array}$ \\
\hline Iharreborde, B. et al. ${ }^{14}$ & 2017 & 35 & $8 \pm 7$ \\
\hline Hassankhani, E.G. et al. ${ }^{15}$ & 2016 & 28 & -5.8 \\
\hline Angelliaume, A. et al. ${ }^{16}$ & 2016 & 35 & 4 \\
\hline Issa, S.P. et al. ${ }^{17}$ & 2016 & 524 & Not informed \\
\hline Pesenti, S. et al. ${ }^{18}$ & 2015 & 29 & 13.2 \\
\hline Ilharreborde, B. et al. ${ }^{19}$ & 2019 & 60 & 7 \\
\hline Overall mean & & & $5.95^{\circ}$ \\
\hline $\begin{array}{l}\text { Mean with only thoracic } \\
\text { sublaminar bands }\end{array}$ & & & $5.95^{\circ}$ \\
\hline
\end{tabular}

\section{Loss of correction}

Eleven studies analyzed postoperative loss of correction after a minimum follow-up period for an overall mean loss of correction of $1.49^{\circ}$ (Figure 4). When we considered only the 9 out of these 11 studies that used only thoracic SBs, the overall mean was $1.33^{\circ}$. (Table 5)

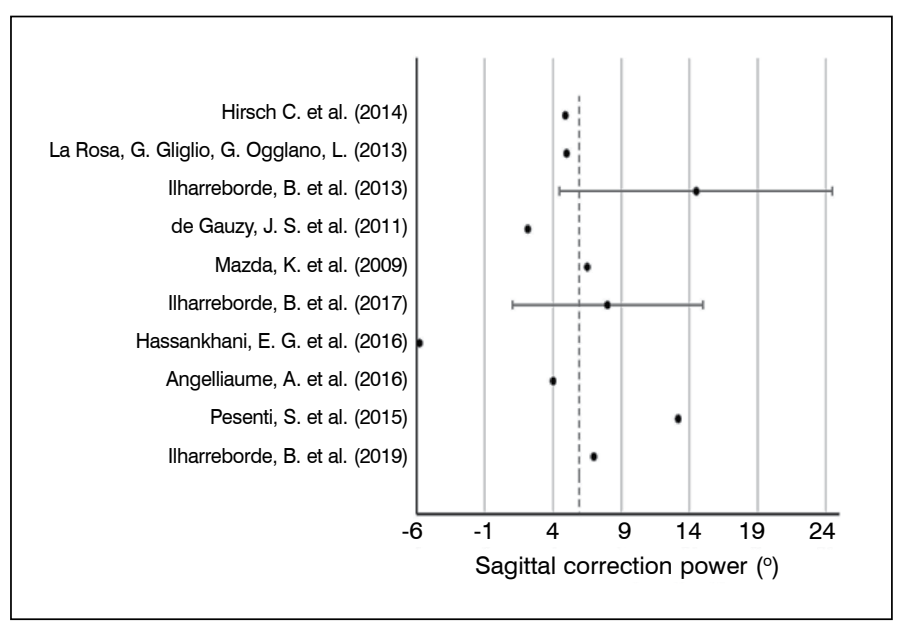

Figure 3. Mean sagittal correction.

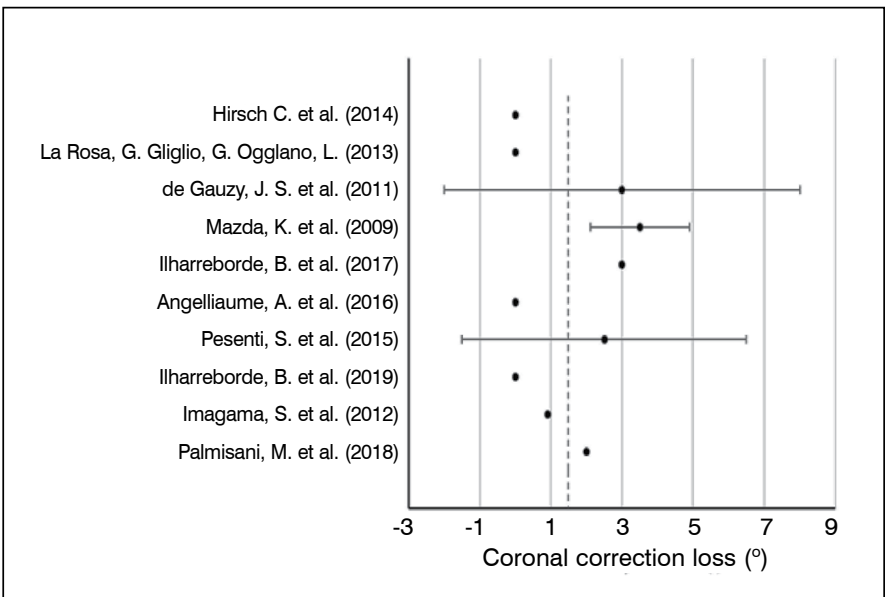

Figure 4. Mean correction loss.

Table 5. Correction loss.

\begin{tabular}{|c|c|c|c|}
\hline Author & Year & $\mathbf{N}$ & $\begin{array}{c}\text { Loss of coronal correction }\left(^{\circ}\right) \\
(\text { mean } \pm \text { SD) }\end{array}$ \\
\hline Hirsch, C. et al. ${ }^{8}$ & 2014 & 20 & 0 \\
\hline La Rosa, et al. ${ }^{9}$ & 2013 & 62 & 0 \\
\hline Ilharreborde, B. et al. ${ }^{10}$ & 2013 & 49 & Not informed \\
\hline Imagama, S. et al. ${ }^{11}$ & 2012 & 30 & 0.9 \\
\hline De Gauzy, J. S. et al. ${ }^{12}$ & 2011 & 29 & $3 \pm 5$ \\
\hline Ilharreborde, B. et al. ${ }^{7}$ & 2010 & 75 & 0 \\
\hline Mazda, K. et al. ${ }^{4}$ & 2009 & 75 & $3.5 \pm 1.4$ \\
\hline Palmisani, M. et al. ${ }^{13}$ & 2018 & 19 & 2 \\
\hline Ilharreborde, B. et al. ${ }^{14}$ & 2017 & 35 & 3 \\
\hline Hassankhani, E.G. et al. ${ }^{15}$ & 2016 & 28 & Not informed \\
\hline Angelliaume, A. et al. ${ }^{16}$ & 2016 & 70 & 0 \\
\hline Issa, S.P. et al. ${ }^{17}$ & 2016 & 524 & Not informed \\
\hline Pesenti, S. et al. ${ }^{18}$ & 2015 & 29 & $2.5 \pm 4$ \\
\hline Ilharreborde, B. et al. ${ }^{19}$ & 2019 & 60 & 0 \\
\hline Overall mean & & & $1.49^{\circ}$ \\
\hline $\begin{array}{l}\text { Mean with only thoracic } \\
\text { sublaminar bands }\end{array}$ & & & $1.33^{\circ}$ \\
\hline
\end{tabular}




\section{DISCUSSION}

The advantage of sublaminar instrumentation, initially developed by Luque in the 1970s, was its being a truly segmental instrumentation with a high power of correction, thanks to the superiority of apical translation. This allowed the elimination of orthotic use, a great advance at that time. ${ }^{20}$

SBs are evolved from the wires developed by Luque. They allow the integration of the advantages of sublaminar wiring without any of its disadvantages. The polyester bands can be inserted with less invasion of the spinal canal than the wires and less risk of spinal cord injury and they have a greater contact surface, permitting greater traction with a lower risk of laminar failure. ${ }^{21}$

This review showed us that the use of SBs in hybrid instrumentations to correct AIS is safe, with a mean overall complication rate of $4.5 \%$ and no neurological complications were observed in all the studies analyzed. It is also noteworthy that no cases of pseudoarthrosis were reported during two years of follow-up. ${ }^{9}$

We found a mean postoperative infection rate of $4 \%$ in the studies. This mean postoperative infection rate is lower than that of the largest study on the subject, which retrospectively involved 524 patients with AIS who had undergone surgery using SBs and had an overall infection rate of $5.3 \% .^{17}$

Coronal correction was like that obtained using pedicle screws, which is the standard used today. The technique achieved a mean reduction of $69 \%$ (ranging from $41-95 \%$ ) in the frontal plane, which is equivalent to the best results published in the literature on AIS corrections. ${ }^{4}$ Loss of correction in the first 2 years of follow-up was minimal with a mean of $1.5^{\circ}$
Restoring sagittal spinal balance continues to be one of the most challenging goals of scoliosis surgery. The reduction of deformity using SBs presented a mean $5^{\circ}$ increase in thoracic kyphosis in normokyphotic and hypokyphotic patients. These results are superior to those previously reported in the literature for thoracic correction using screws. ${ }^{4}$ The results are matched in the literature, which shows that hybrid constructions increase sagittal correction, which may also reduce the risk of junctional kyphosis. ${ }^{22,23}$

Mean bleeding also was less than the means presented by the other most-used hybrid instrumentations, at around $682.5 \mathrm{~mL}$, compared to instrumentation using hooks, which average $1090 \mathrm{~mL}$. Similarly, the mean surgical time of 228.6 minutes is less than the mean surgical time of the other hybrid constructions, especially the hook at an average of 295 minutes. ${ }^{7}$

\section{CONCLUSIONS}

In conclusion, the results of this review confirm that hybrid constructions using SBs to correct spinal curvature in patients with AIS are safe. It is effective in correcting deformities in the coronal plane. Today, SBs seem to provide better correction in the sagittal plane than other devices, especially in constructions using screws and they reduce mean surgical time and blood loss.

All authors declare no potential conflict of interest related to this article.

CONTRIBUTION OF THE AUTHORS: Each author made significant individual contributions to this manuscript. MTD was the study designer and made decisions about the choice of the abstracts. RVTS and GMA wrote the manuscript and participated in the analysis of the abstracts. BAEES, NCM, VNN, and PFJ assisted with the bibliographical research. SD and MFR helped prepare the manuscript.

\section{REFERENCES}

1. Clements DH, Betz RR, Newton PO, Rohmiller M, Marks M, Bastrom T Correlation of Scoliosis Curve Correction With the Number and Type of Fixation Anchors. Spine (Phila Pa 1976). 2009;34(20):2147-50.

2. Watanabe K, Nakamura T, Iwanami A, Hosogane N, Tsuij T, Ishii K, et al. Vertebral derotation in adolescent idiopathic scoliosis causes hypokyphosis of the thoracic spine. BMC Musculoskelet Disord. 2012;13:99.

3. Clément JL, Chau E, Vallade M-J, Geoffray A. Simultaneous translation on two rods is an effective method for correction of hypokyphosis in AIS: Radiographic results of 24 hypokyphotic thoracic scoliosis with 2 years minimum follow-up. 2011;20(7):1149-56.

4. Mazda K, Ilharreborde B, Even J, Lefevre Y, Fitoussi F, Penneçot G-F. Efficacy and safety of posteromedial translation for correction of thoracic curves in adolescent idiopathic scoliosis using a new connection to the spine: the Universal Clamp. Eur Spine J. 2008;18(2):158-69.

5. Ilharreborde B, Vidal C, Skalli W, Mazda K. Sagittal alignment of the cervical spine in adolescent idiopathic scoliosis treated by posteromedial translation. Eur Spine J. 2012:22(2):330-7

6. Ilharreborde B, Simon AL, Ferrero E, Mazda K. How to Optimize Axial Correction Without Altering Thoracic Sagittal Alignment in Hybrid Constructs With Sublaminar Bands: Description of the "Frame" Technique. Spine Deform. $2019 ; 7(2): 245-53$

7. Ilharreborde B, Even J, Lefevre Y, Fitoussi F, Presedo A, Penneçot GF, et al. Hybrid Constructs for Tridimensional Correction of the Thoracic Spine in Adolescent Idiopathic Scoliosis A Comparative Analysis of Universal Clamps Versus Hooks. Spine (Phila Pa 1976). 2010;35(3):306-14.

8. Hirsch C, Ilharrebordeb B, Fournierc J, Mazdab K, Bonnardc C. Adolescent idiopathic scoliosis correction achieved by posteromedial translation using polyester bands: A comparative study of subtransverse process versus sublaminar fixation. Orthop Traumatol Surg Res. 2014;100(7):791-5.

9. La Rosa G, Giglio G, Oggiano L. The Universal Clamp hybrid system: a safe technique to correct deformity and restore kyphosis in adolescent idiopathic scoliosis. Eur Spine J. 2013;22(Suppl 6):S823-8.

10. Imagama S, Ito Z, Wakao N, Ando K, Hirano K, Tauchi R, et al. Posterior Surgery for Adolescent Idiopathic Scoliosis With Pedicle Screws and Ultra-high Molecular Weight Polyethylene Tape: Achieving the Ideal Thoracic Kyphosis. J Spinal Disord Tech. 2012;29(8):E376-83.

11. de Gauzy JS, Jouve J, Accadbled F, Blondel B, Bollini G. Use of the Universal Clamp in adolescent idiopathic scoliosis for deformity correction and as an adjunct to fusion: 2-year follow-up. J Child Orthop. 2011:5(4):273-82.

12. Palmisani M, Dema E, Cervellati S, Palmisani R. Hybrid constructs pedicle screw with apical sublaminar bands versus pedicle screws only for surgical correction of adolescent idiopathic scoliosis. Eur Spine J. 2018;27(Suppl 2):150-6.

13. Ilharreborde B, Pesenti S, Ferrero E, Accadbled F, Jouve JL, De Gauzy JS, et al. Correction of hypokyphosis in thoracic adolescent idiopathic scoliosis using sublaminar bands: a 3D multicenter study. Eur Spine J. 2017;27(2):350-7.

14. Ghayem Hasankhani E, Omidi- Kashani F, Moradkhani S, Ghayyem Hassankhani G, Shakeri M. Comparison of Clinical and Radiologic Outcome of Adolescent Idiopathic Scoliosis Treated with Hybrid Hook-Screw Instrumentation versus Universal Clamp System. Adv Med. 2016;2016:1-5.

15. Angelliaume A, Ferrero E, Mazda K, Le Hanneur M, Accabled F, de Gauzy JS, et al. Titanium vs cobalt chromium: what is the best rod material to enhance adolescent idiopathic scoliosis correction with sublaminar bands? Eur Spine J. 2017:26(6):1732-8.

16. Issa SP, Angelliaume A, Vidal C, Mazda K, Ilharreborde B. Do Sublaminar Polyester Bands Affect the Outcomes of Postoperative Infections After Adolescent Idiopathic Scoliosis Surgery? J Pediatr Orthop. 2016;37(8):e524-9.

17. Pesenti S, Blondel B, Peltier E, Choufani E, Bollini G, Jouve J. Interest of T1 parameters for sagittal alignment evaluation of adolescent idiopathic scoliosis patients. Eur Spine J. 2015;25(2):424-9.

18. Cheng I, Kim Y, Gupta MC, Bridwell KH, Hurford RK, Lee SS, et al. Apical Sublaminar Wires Versus Pedicle Screws - Provides Better Results for Surgical Correction of Adolescent Idiopathic Scoliosis? Spine (Phila Pa 1976). 2005;30(18):2104-12.

19. Lamartina $C$, Cecchinato R. Selective thoracolumbar instrumentation with pedicle screws and sublaminar bands in adolescent idiopathic scoliosis. Eur Spine J. 2011;20(12):2286-7.

20. Kim YJ, Lenke LG, Bridwell KH, Kim J, Cho SK, Cheh G, et al. Proximal Junctional Kyphosis in Adolescent Idiopathic Scoliosis After 3 Different Types of Posterior Segmental Spinal Instrumentation and Fusions Incidence and Risk Factor Analysis of 410 Cases. Spine (Phila Pa 1976). 2007:32(24):2731-8.

21. Vora V, Crawford A, Babekhir N, Boachie-Adjei O, Lenke L, Peskin M, et al. A Pedicle Screw Construct Gives an Enhanced Posterior Correction of Adolescent Idiopathic Scoliosis When Compared With Other Constructs Myth or Reality. Spine (Phila Pa 1976). 2007;32(17):1869-74 